\begin{tabular}{|l|l|l||}
\hline \multicolumn{2}{|c|}{ PublisherInfo } \\
\hline \hline PublisherName & $:$ & BioMed Central \\
\hline \hline PublisherLocation & $:$ & London \\
\hline \hline PublisherImprintName & $:$ & BioMed Central \\
\hline \hline
\end{tabular}

\title{
Anti-inflammatory pretreatments for lung injury
}

\begin{tabular}{|l|l|l||}
\hline \multicolumn{2}{|c||}{ ArticleInfo } \\
\hline \hline ArticleID & $:$ & 4091 \\
\hline \hline ArticleDOI & $:$ & $10.1186 /$ ccf-1999-1422 \\
\hline \hline ArticleCitationID & $:$ & 1422 \\
\hline \hline ArticleSequenceNumber & $:$ & 28 \\
\hline \hline ArticleCategory & $:$ & Paper Report \\
\hline ArticleFirstPage & $:$ & 1 \\
\hline \hline ArticleLastPage & $:$ & 4 \\
\hline \hline & & RegistrationDate : 1999-8-26 \\
ArticleHistory & $:$ & OnlineDate \\
\hline \hline ArticleCopyright & $:$ & Current Science Ltd1999-8-26 \\
\hline \hline ArticleGrants & $:$ & \\
\hline \hline ArticleContext & $:$ & 130541111 \\
\hline \hline
\end{tabular}




\section{Keywords}

Cytokines, inflammation, lung injury

\section{Comments}

This complex study illustrates the difficulties in manipulating inflammatory mediators. Blocking TNF- $\alpha$ does not have the expected effect and, conversely, two strategies thought to act on the same mediator show different effects. The study provides little information of clinical relevance but perhaps helps to establish a wider base of knowledge on which future investigations can be based.

\section{Introduction}

Bacterial infections frequently occur following acid aspiration, both in the directly exposed and nonexposed lung. Anti-inflammatory strategies can reduce the indirect and acid induced lung injury. One mediator of inflammation is tumour necrosis factor alpha (TNF- $\alpha$ ). This study compared two mechanisms of TNF- $\alpha$ blockade. Pentoxifylline which inhibits production of TNF- $\alpha$ mRNA and protein and anti-TNF- $\alpha$ antiserum.

\section{Aims}

To determine whether pentoxifylline or anti-TNF- $\alpha$ would differ in their effects on airspace bacterial challenge given to animals $24 \mathrm{~h}$ after acid induced injury.

\section{Methods}

New Zealand white rabbits were anesthetised and subjected to one of the following protocols: 
Group one were given intravenous saline plus phosphate buffered saline given intratracheally (control).

Group two, intravenous saline plus intratracheal hydrochloric acid $(\mathrm{HCl})$ to the right lower lobes.

Group three received non-immune serum plus $\mathrm{HCl}$ intratracheally.

Group four received pentoxifylline given intravenously and $\mathrm{HCl}$ intratracheally followed by an infusion of pentoxifylline $6 \mathrm{ml}$ per $\mathrm{Kg}$ per hour for $8 \mathrm{~h}$.

Group five received anti-TNF- $\alpha$ IV plus $\mathrm{HCl}$ intratracheally. The rabbits in this group were then allowed to wake and were killed after an interval of $8 \mathrm{~h}$. The lungs were removed via a sternotomy. Bronchealveolar lavage (BAL)was performed and blood samples taken for IL-8, TNF- $\alpha$ and myeloperoxidase assays. An additional 16 rabbits (four groups of four) were pretreated with pentoxifylline, anti-TNF- $\alpha$ or saline, as described above. Twenty four hours after the instillation of acid a bacterial innoculum was instilled into the non exposed lung. Epithelial and alveolar epithelial barrier permeability to protein was measured by calculating the amount of radioactive iodine tracer present in air spaces and plasma after instillation into the lungs.

\section{Results}

Pretreatment with either anti-TNF- $\alpha$ or pentoxifylline prevented the reduction in $\mathrm{PaO}_{2}$ seen in the untreated rabbits. There was no significant difference between the two pretreatments. Both pretreatments also reduced the the acid induced increase in myeloperoxidase (indicative of neutrophil activation). The pretreatment prevented an increase in extravascular lung water (EVLW) in the non acid instilled lung, but not in the acid instilled lung. Pentoxifylline and anti-TNF- $\alpha$ both blocked TNF activity as measured by BAL samples. Pentoxifylline also inhibited rises in IL-8 in BAL samples of the non instilled lungs. In the groups with bacterial injury, only pentoxifylline reduced EVLW and prevented a drop in $\mathrm{PaO}_{2}$.

\section{Discussion}

This study showed that the two anti-inflammatory strategies were similar in their ability to inhibit initial lung injury brought about by unilateral acid instillation. Both agents limited the elevation in EVLW in the non instilled lung, preserved gas exchange and inhibited myeloperoxidase activity in the instilled, non instilled lung. This leads to the conclusion that pentoxifylline and anti-TNF- $\alpha$ both prevent the initial direct cytokine mediated lung injury. Pentoxifylline appeared to be the only agent capable of blocking most of the lung injury as measured by the increase in EVLW, accumulation of vascular protein tracer and the efflux of alveolar protein tracer. Arterial oxygenation in the pentoxifylline was not statistically significantly different from the anti-TNF- $\alpha$ group but there was no overlap between the two groups. Thus pentoxifylline seems to improve delayed bacterial induced lung injury. Anti-TNF- $\alpha$ did not show any benefit against subsequent bacterial infection and this may be due to TNFs role in host 
defence. Pentoxifylline effects the generation of TNF- $\alpha$ and although plasma levels were reduced local TNF- $\alpha$ activity in the lungs may have been preserved. Additionally, pentoxifylline has other modes of anti-inflammatory action, specifically, it leads to reduced IL-8 levels which may be significant.

Potential sources of error include the small number of animals studied, and the fact that $100 \%$ oxygen was administered during the experiments. However, any lung injury caused in this way should have been constant in both groups. The clinical relevance of these findings, are that therapies that reduce acute lung injury in response to acid aspiration may not reduce the severity of subsequent bacterial infection.

\section{References}

1. Miyazaki H, Broaddus VC, Weiner-Kronish JP, et al: The effects of two anti-inflammatory pretreatments on bacterial induced lung injury. Anesthesiology. 1999, 90: 1650-1662. 